\title{
MODEL PEMBELAJARAN HIGHER ORDER THINKING SKILL (HOTS) DI MASA PANDEMI COVID 19
}

\author{
Harkinal Mikly, Arie Frits Kawulur, Allen Manongko, Edwin Wantah \\ Universitas Negeri Manado (UNIMA) Sulawesi Utara, Indonesia \\ Email: harkinalmikly@gmail.com, ariekawulur@unima.ac.id, \\ ma.allen1974@gmail.com, edwinwantah999701@gmail.com
}

\begin{abstract}
Abstrak
Pendidikan merupakan proses untuk meningkatkan, memperbaiki, mengubah pengetahuan, keterampilan, sikap serta tata laku seseorang atau kelompok orang dalam usaha mencerdaskan kehidupan manusia melalui kegiatan bimbingan pengajaran dan pelatihan. Penelitian ini untuk mengetahui Hasil Belajar Dengan Menggunakan model pembelajaran Higher Order Thinking Skill (HOTS) di masa Pandemi Covid-19. Penelitian ini menggunakan pendekatan kuantitatif (eksperimen semu). Metode pengumpulan menggunakan Tes, Lembar Observasi, Dokumentasi, dan Wawancara. Populasi dari penelitian ini adalah seluruh SMK Di Minahasa Selatan. Dengan mengambil 1 sekolah unggulan yang di jadikan sampel eksperimen. Dan 3 sekolah menengah sebagai kelas control, dan Sampel yang diambil dalam penelitian ini adalah siswa SMK yang dipilih dari SMKSMK yang direkomendasi oleh Dinas Pendidikan Kabupaten.Minahasa Selatan dengan pertimbangan fasilitas pembelajaran kelas tertentu yang memadai untuk di jadikan penelitian. Berdasarkan hasil penelitian, dapat disimpulkan bahwa hasil belajar siswa di masa pandemi covid-19, meningkat setelah diterapkannya model pembelajaran Higher Order Thinking Skill (HOTS).
\end{abstract}

Kata Kunci: keterampilan berpikir; order lebih tinggi; Covid-19

\section{Abstract}

Education is a process to improve, improve, change the knowledge, skills, attitudes and behaviors of a person or group of people in an effort to educate human life through teaching and training guidance activities. This study is to find out the results of learning using higher order thinking skill (HOTS) learning model during the Covid-19 pandemic. This study uses quantitative approach (pseudo experiment). The collection method uses Tes, Lembar Observasi, Dokumentasi, and Wawancara. The population of this study is the entire vocational school in South Minahasa. By taking 1 excellent school that is used as a sample experiment. And 3 secondary schools as a control class, and Sampel takendalampenelitian ini adalah siswa SMK yangdipilihdari SMK-SMK yangdirekomendasi oled inas Pendidikan Kabupaten. South Minahasa denganpertimbanganfasilitaspembelajara $n$ certain classes yang memadai untuk made penelitian. Based on the results of the study, it can be concluded that student learning outcomes in the pandemic covid-19, improved after the implementation of the Higher Order Thinking learning model Skill (HOTS).

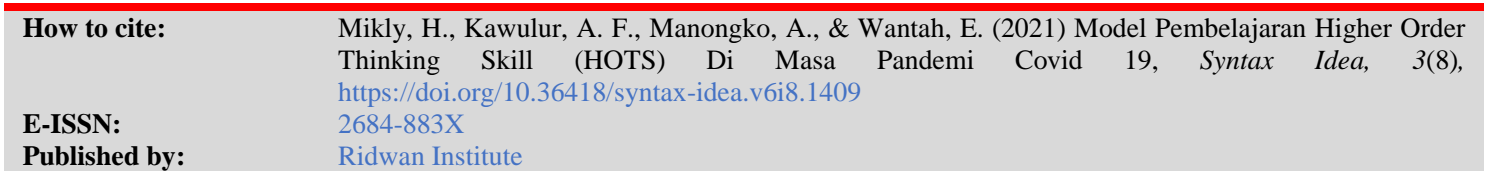


Keywords: higher order; thinking skill; Covid-19

\section{Pendahuluan}

Pendidikan sebagai sebuah kegiatan dan proses aktivitas yang disengaja merupakan gejala masyarakat ketika sudah mulai disadari pentingnya upaya untuk membentuk, mengarahkan, dan mengatur manusia sebagaimana dicita-citakan masyarakat (Gunawan, 2012).

Pendidikan pada dasarnya adalah proses. Pendidikan merupakan usaha sadar dan terencana untuk mewujudkan manusia yang memiliki kemampuan spiritual keagamaan, pengendalian diri, kepribadian, kecerdasan, akhlak mulia serta keterampilan yang diperlukan dirinya, masyarakat bangsa dan negara (Ilham, 2019). Undang-undang Sistem Pendidikan Nasional No. 20 Tahun 2003, menyatakan bahwa tujuan pendidikan nasional adalah mencerdaskan kehidupan bangsa dan mengembangkan manusia Indonesia seutuhnya, yaitu manusia yang bertakwa kepada Tuhan Yang Maha Esa dan berbudi pekerti luhur, memiliki pengetahuan dan keterempilan, kesehatan jasmani dan rohani, kepribadian yang mantap dan mandiri serta bertanggung jawab kemasyarakatan dan kebangsaan (Undang-Undang 2003).

Adapun melalui penelitian terdahulu oleh Nikhil Sachdev pada tahun 2007 yang berjudul "An Examination of the Wage Productivity Gap", mengenai tingkat kesejahteraan serikat pekerja menurun karena mempengaruhi produktivitas kesenjangan upah. Secara keseluruhan bahwa pengaruh upah riil dan produktivitas ini lebih mengarah pada keuntungan perusahaan bukan pada kesejahteraan serikat pekerjanya (Widyastuti, 2012).

Kualitas pendidikan menentukan sumber daya manusia, dalam menghadapi era persaingan yang sangat ketat di dunia kerja. Era revolusi industri 4.0 sangat berdampak pada peran guru sebagai komponen pendidikan/ pembelajaran. Sebagai guru harus professional dalam proses pembelajaran sekaligus kunci keberhasilan belajar peserta didik dan menghasilkan lulusan yang berkualitas. Guru profesional adalah guru yang kompeten dalam membangun dan mengembangkan proses pembelajaran yang baik dan efektif sehingga dapat menghasilkan peserta didik yang pintar dan pendidikan yang berkualitas (Bali \& Hajriyah, 2020).

Sehubungan dengan pendidikan, model pembelajaran yang digunakan pada saat ini harus sesuai dengan kurikulum yang ada dimana pada saat ini Indonesia menggunakan kurikulum 2013 yang menekankan pada kecerdasan tingkat tinggi (Higher Order Thinking Skill) yang di bingkai oleh sikap ketuhanan dan nilai-nilai sosial yang terintegrasi dalam proses pembelajaran. Siswa harus dapat berpikir secara kritis dan kreatif untuk meningkatkan berpikir tingkat tinggi (Bali \& Hajriyah, 2020).

Menurut (Basis, Manongko, \& Tiwow, 2020) HOTS (Higher Order Thinking Skill) merupakan proses berpikir yang tidak sekedar menghafal dan menyampaikan kembali informasi yang diketahui. Kemampuan berpikir tingkat tinggi merupakan kemampuan menghubungkan, memanipulasi, dan mentransformasi pengetahuan serta 
pengalaman yang sudah dimiliki untuk berpikir secara kritis dan kreatif dalam upaya menentukan keputusan dan memecahkan masalah pada situasi baru, dalam konteks pembelajaran berpikir tingkat tinggi terjadi ketika peserta didik mampu menghubungkan dan mentransformasi pengetahuan yang sudah dimilikinya dengan halhal atau masalah-masalah yang belum pernah diajarkan dalam pembelajaran. Keterampilan berpikir pada tingkat yang lebih tinggi tidak dapat diperoleh secara langsung sehingga perlu dilatihkan melalui kegiatan pembelajaran.

Implementasi Kurikulum 2013 menurut Permendikbud No. 22 Tahun 2016 tentang Standar Proses menggunakan 3 (tiga) model pembelajaran yang diharapkan dapat membentuk perilaku saintifik, sosial serta mengembangkan rasa keingintahuan. Ketiga model tersebut adalah model Pembelajaran Melalui Penyingkapan/Penemuan (Discovery/Inquiry Learning), model Pembelajaran Berbasis Masalah (Problem-based Learning/PBL) dan model Pembelajaran Berbasis Projek (Project- based Learning/PJBL) (Fauzi, Zainuddin, \& Atok, 2018),

Keberhasilan peserta didik dalam kemampuan berpikir tingkat tinggi atau Higher Order Thinking skill (HOTS) tidak luput dari bantuan peran pendidik yang telah memberikan pembelajaran secara baik dan efektif untuk meningkatkan kemampuan berpikir tingkat tinggi pada peserta didik. kemampuan tersebut dapat didukung dengan berbagai faktor yaitu pengusaan materi oleh tenaga pendidik, kerativitas dalam proses pembelajaran sehingga mudah di pahami peserta didik. Selain itu juga, Model pembelajaran dan penyajian materi yang akan diberikan menjadi faktor penting dalam keberhasilan proses pembalajaran (Purba \& Basni, 2020).

Berdasarkan hasil pra penilitian melalui wawancara pada beberapa guru di sekolah menengah kejuruan yang ada di Kabupaten Minahasa Selatan. Melalui tenaga pendidik di sekolah mengatakan bahwa sekolah saat ini sudah menggunakan kurikulum 2013 yang berbasis HOTS dengan menggunakan model pembelajaran yang tentunya sudah berbasis HOTS sehingga tingkat keberhasilan guru dalam menggunakan model pembelajaran. Pendidik di sekolah tersebut menggunakan bahan ajar yang berupa buku cetak yang sudah disediakan sekolah. Akan tetapi belum menerapkan model pembelajaran model pembelajaran HOTS (Setiawan, 2018).

Berdasarkan pernyataan di atas diperlukan pengembangan keterampilan berpikir tingkat tinggi (HOTS) dalam proses pembelajaran dan evaluasinya. Kita ketahui bersama pada saat ini seluruh belahan dunia sedang dilanda wabah penyakit COVID 19 terlebih khusus di Negara kita Indonesia hal itu berdampak salah satunya dalam dunia pendidikan sehingga menteri pendidikan Republik Indonesia mengubah peraturan yang awalnya kegiatan pembelajaran siswa dan guru dilakukan disekolah dan sekarang kegiatan pembelajaran dilakukan dari rumah.

Pandemi COVID 19 saat ini menekankan siswa untuk belajar dari rumah sehingga membuat tenaga pendidik harus lebih kreatif dalam menyampaikan materi bahkan dalam menggunakan model pembelajaran didukung dengan fasilitas yang dimiliki tenaga pendidik, sekolah maupun siswa (Setiawan, 2018). 
Saat pandemi COVID 19 ini membuat tenaga pendidik untuk lebih mengembangkan model pembelajaran sesuai dengan kurikulum yang digunakan melalui bahan ajar maupun tugas rumah yang mudah di pahami dan diterima oleh siswa. Akan tetapi, pengembangan model pembelajaran pada saat ini tidak merata karena terhalangi oleh beberapa faktor seperti alat teknologi maupun keterbatasan biaya (kuota internet). Penelitian ini untuk mengetahui Hasil Belajar Dengan Menggunakan model pembelajaran Higher Order Thinking Skill (HOTS) di masa Pandemi Covid-19. Penelitian ini menggunakan pendekatan kuantitatif (eksperimen semu).

\section{Metode Penelitian}

Penelitian ini dilaksanakan dalam bentuk Penelitian Kuantitatif (Eksperimen). Eksperimen semu (quasi experiment) dengan metode kuantitatif. Tujuan metode kuantitatif menurut (Sugiyono, 2010) adalah menunjukan hubungan antar variabel, menguji teori, serta mencari generalisasi yang mempunyai nilai prediktif. Penelitian eksperimen merupakan metode penelitian yang paling produktif, yang dapat menjawab hipotesis yang berkaitan dengan hubungan sebab akibat suatu variabel.

Menurut (Mulyati, 2019) Populasi adalah keseluruhan subjek penelitian. Populasi dari penelitian ini adalah seluruh SMK Di Minahasa Selatan. Dengan mengambil 1 sekolah unggulan yang di jadikan sampel eksperimen. Dan 3 sekolah menengah sebagai kelas kontrol.

Sampel adalah sebagian atau wakil populasi yang diteliti (Amir, 2015) Sampel dalam penelitian ini adalah siswa SMK yang dipilih dari SMK-SMK yang direkomendasi oleh Dinas Pendidikan KAB. Minahasa Selatan dengan pertimbangan fasilitas pembelajaran kelas tertentu yang memadai untuk di jadikan penelitian.

\section{Hasil dan Pembahasan}

\section{A. Hasil Penelitian}

\section{Uji Normalitas Data}

Uji normalitas yaitu untuk melihat apakah data berdistribusi normal atau tidak dengan menngunakan one-sampel komogrorov-smirnov dengan dasar pengambilan keputusan yaitu jika Asymp. Sig. (2-tailed) > 0,05 Maka data berdistribusi normal

Tabel 1

Uji Normalitas Data

\begin{tabular}{|c|c|c|c|c|}
\hline \multicolumn{5}{|c|}{ One-Sample Kolmogorov-Smirnov Test } \\
\hline & & pre_K1 & pre_K2 & pre_k3 \\
\hline $\mathrm{N}$ & & 30 & 30 & 30 \\
\hline \multirow[t]{2}{*}{ Normal Parameters ${ }^{\mathrm{a}, \mathrm{b}}$} & Mean & 34.5333 & 38.6667 & 32.8333 \\
\hline & $\begin{array}{l}\text { Std. } \\
\text { Deviation }\end{array}$ & 4.04912 & 3.61351 & 5.64516 \\
\hline \multirow{3}{*}{$\begin{array}{l}\text { Most Extreme } \\
\text { Differences }\end{array}$} & Absolute & .098 & .141 & .136 \\
\hline & Positi & .081 & .078 & .118 \\
\hline & Negative & -.098 & -.141 & -.136 \\
\hline
\end{tabular}




\begin{tabular}{lr|r|r}
\hline Test Statistic & .098 & .141 & .136 \\
\hline Asymp. Sig. (2-tailed) & $.200^{\mathrm{c}, \mathrm{d}}$ & $.133^{\mathrm{c}}$ & $.161^{\mathrm{c}}$ \\
\hline a. Test distribution is Normal. & & \\
\hline b. Calculated from data. \\
\hline c. Lilliefors Significance Correction. \\
\hline d. This is a lower bound of the true significance. \\
\hline
\end{tabular}

\section{Uji Hipotesis}

Teknik analisis yang digunakan untuk menguji hipotesis dalam penelitian ini di tentukan setelah uji prasyarat data (normalitas dan homogen). Berdasarkan uji prasyarat data yang di lakukan dapat di lihat data memenuhi pra syarat untuk menggunakan analisis parametrik. Untuk pengujian beda dua rata-rata pre post dan post test, dilakukan dengan uji pairet sampel t-test. Selanjutnya untuk menguji post test beda dua rata-rata, dilakukan dengan independen sampel t-test. Dan untuk menguji beda beberapa rata-rata post test kelas kontrol dan eksperimen, dilakukan dengan anova one way.

a. Uji beda pre test dan post test (paired sampel t-test) kelas eksperimen

1. Uji Beda 2 Rata-Rata Kelas Eksperimen Discovery/Inquiry Learning

Dasar pengambilan keputusan jika nilai signifikan tailed $<$ dari 0.05 maka terdapat perbedaan hasil belajar (HOTS) sebelum dan sesudah menerapkan Discovery/Inquiry Learning, jika sebaliknya maka, tidak terdapat perbedaan hasil belajar (HOTS) sebelum dan sesudah menerakan Discovery/Inquiry Learning.

Berdasarkan hasil uji beda pre-test dan post test, ditemukan nilai sig (2tailed) < dari 0,05 maka, terdapat perbedaan hasil belajar (HOST) dengan menerapkan Discovery/Inquiry Learning.

2. Uji Beda 2 Rata-Rata Kelas Eksperimen Problem-Based Learning

Dasar pengambilan keputusan jika nilai signifikan tailed $<$ dari 0.05 maka terdapat perbedaan hasil belajar (HOTS) sebelum dan sesudah menerapkan Problem-Based Learning, jika sebaliknya maka, tidak terdapat perbedaan hasil belajar (HOTS) sebelum dan sesudah menerakan Problem-Based Learning.

Berdasarkan hasil uji beda 2 rata - rata kelas Eksperimen Problem-Based Learning, ditemukan nilai sig (2-tailed) < dari 0,05 maka, terdapat perbedaan hasil belajar (HOST) dengan menerapkan Problem-Based Learning.

3. Uji Beda 2 Rata-Rata Kelas Eksperimen Project-Based Learning

Dasar pengambilan keputusan jika nilai signifikan tailed $<$ dari 0.05 maka terdapat perbedaan hasil belajar (HOTS) sebelum dan sesudah menerapkan Project-Based Learning, jika sebaliknya maka, tidak terdapat perbedaan hasil belajar (HOTS) sebelum dan sesudah menerakan Project-Based Learning.

Berdasarkan hasil uji beda 2 rata - rata kelas Eksperimen Project-Based Learning, ditemukan nilai sig (2-tailed) < dari 0,05 maka, terdapat perbedaan hasil belajar (HOST) dengan menerapkan Project-Based Learning.

\section{b. Uji beda pre test dan post test (paired sampel t-test) kelas kontrol}

1. Uji Beda 2 Rata-Rata Kelas kontrol 1 yang tidak menerapkan Discovery/Inquiry Learning 
Dasar pengambilan keputusan jika nilai signifikan tailed $<$ dari 0.05 maka terdapat perbedaan hasil belajar (HOTS) sebelum dan sesudah di kelas kontol ke 1 yang tidak menerapkan Discovery/Inquiry Learning, jika sebaliknya maka, tidak terdapat perbedaan hasil belajar (HOTS) sebelum dan sesudah di kelas kontrol ke 1 yang tidak menerakan Discovery/Inquiry Learning.

Berdasarkan hasil uji Beda 2 Rata-Rata Kelas kontrol 1 yang tidak menerapkan Discovery/Inquiry Learning, ditemukan nilai sig (2-tailed) < dari 0,05 maka, terdapat perbedaan hasil belajar (HOST) pada kelas kontrol ke 1 yang tidak menerapkan Discovery/Inquiry Learning.

2. Uji Beda 2 Rata-Rata Kelas konrol 2 yang tidak menerapkan Problem-Based Learning

Dasar pengambilan keputusan jika nilai signifikan tailed < dari 0.05 maka terdapat perbedaan hasil belajar (HOTS) sebelum dan sesudah di kelas kontol ke 2 yang tidak menerapkan Problem-Based Learning., jika sebaliknya maka, tidak terdapat perbedaan hasil belajar (HOTS) sebelum dan sesudah di kelas kontol ke 2 yang tidak menerakan Problem-Based Learning.

Berdasarkan hasil Uji Beda 2 Rata-Rata Kelas konrol 2 yang tidak menerapkan Problem-Based Learning, ditemukan nilai sig (2-tailed) $<$ dari 0,05 maka, terdapat perbedaan hasil belajar (HOST) pada kelas kontrol ke-2 yang tidak menerapkan Problem-Based Learning.

3. Uji Beda 2 Rata-Rata Kelas konrol 3 yang tidak menerapkan Project-Based Learning

Dasar pengambilan keputusan jika nilai signifikan tailed $<$ dari 0.05 maka terdapat perbedaan hasil belajar (HOTS) sebelum dan sesudah di kelas kontol ke 3 yang tidak menerapkan Project-Based Learning, jika sebaliknya maka, tidak terdapat perbedaan hasil belajar (HOTS) sebelum dan sesudah di kelas kontol ke 3 yang tidak menerakan Project-Based Learning.

Berdasarkan hasil uji Uji Beda 2 Rata-Rata Kelas konrol 3 yang tidak menerapkan Project-Based Learning, ditemukan nilai sig (2-tailed) < dari 0,05 maka, terdapat perbedaan hasil belajar (HOST) pada kelas kontrol ke-3 yang tidak menerapkan Project-Based Learning.

\section{c. Uji independent sampel t-test}

1. Uji beda 2 rata-rata post test kelas ekspermen Discovery/Inquiry Learning dan post test kelas kontol 1

Dasar pengambilan keputusan uji independen sampel t-test jika t-hitung > ttabel maka terdapat perbedaan yang signifikan hasil belajar (HOTS) antara kelas ekspermen Discovery/Inquiry Learningm dan post test kelas kontol 1

Berdasarkan hasil Uji beda 2 rata-rata post test kelas ekspermen Discovery/Inquiry Learning dan post test kelas kontol 1, ditemukan nilai sig (2tailed) < dari 0,05 maka, terdapat perbedaan yang signifikan hasil belajar (HOTS) antara kelas ekspermen Discovery/Inquiry Learningm dan post test kelas kontol 1 
2. Uji beda 2 rata-rata post test kelas ekspermen Problem-Based Learning dan post test kelas kontol

Dasar pengambilan keputusan uji independen sampel t-test jika t-hitung $>\mathrm{t}$ tabel maka terdapat perbedaan yang signifikan hasil belajar (HOTS) antara kelas ekspermen Problem-Based Learning dan post test kelas kontol 2.

Berdasarkan hasil Uji beda 2 rata-rata post test kelas ekspermen ProblemBased Learning dan post test kelas kontol, ditemukan nilai sig (2-tailed) < dari 0,05 maka, terdapat perbedaan yang signifikan hasil belajar (HOTS) antara kelas ekspermen Problem-Based Learning dan post test kelas kontol 2

3. Uji beda 2 rata-rata post test kelas ekspermen Project-Based Learning dan post test kelas kontol 3

Dasar pengambilan keputusan uji independen sampel t-test jika t-hitung > ttabel maka terdapat perbedaan yang signifikan hasil belajar (HOTS) antara kelas ekspermen Project-Based Learning dan post test kelas kontol 3.

Berdasarkan hasil Uji beda 2 rata-rata post test kelas ekspermen ProjectBased Learning dan post test kelas kontol 3, ditemukan nilai sig (2-tailed) < dari 0,05 maka, terdapat perbedaan yang signifikan hasil belajar (HOTS) antara kelas ekspermen Project-Based Learning dan post test kelas kontol 3.

\section{d. Uji ANOVA One-Way}

Dasar pengambilan keputusan uji ANOVA One-Way jika f-hitung > f-tabel dari 0,05 maka terdapat perbedaan yang signifikan antara hasil belajar (HOTS) antara post test kelas ekspermen dan post test kelas kontol yang tidak menggunakan tretmen.

Berdasarkan hasil uji ANOVA One-Way, ditemukan nilai f-hitung > dari 0,05 maka, terdapat perbedaan yang signifikan antara hasil belajar (HOTS) antara post test kelas ekspermen dan post test kelas kontol yang tidak menggunakan treatmen.

\section{e. Uji N-Gain}

Peningkatan hasil belajar siswa kelas eksperimen dan kontrol diperoleh dari data $\mathrm{N}$-gain dari hasil pre test dan post test. Peningkatan dari hasil pre tes ke pos test akan terlihat dengan uji N-Gain dengan melihat nilai katogori dan tafsiran efektivitas NGAIN.

\section{Uji N-Gain kelas ekspermen Discovery/Inquiry Learning}

Hasil uji N-Gain kelas ekspermen Discovery/Inquiry Learning menunjukan nilai rata-rata yang diperoleh 0,64 dengan demikian berada dalam kategori sedang. Dan nilai pengambilan keputusan tafsiran efektivitas uji N-GAIN sebesar 64,25 berada pada kategori cukup efektif.

\section{Uji N-Gain kelas ekspermen Problem-Based Learning}

Hasil Uji N-Gain kelas ekspermen Problem-Based Learning menunjukan nilai rata-rata yang diperoleh 0,43 dengan demikian berada dalam kategori sedang. Dan nilai pengambilan keputusan tafsiran efektivitas uji N-GAIN sebesar 42,79 berada pada kategori kurang efektif. 


\section{Uji N-Gain kelas ekspermen Project-Based Learning}

Hasil Uji N-Gain kelas ekspermen Project-Based Learning menunjukan nilai rata-rata yang diperoleh 0,54 dengan demikian berada dalam kategori sedang. Dan nilai pengambilan keputusan tafsiran efektivitas uji N-GAIN sebesar 54,01 berada pada kategori kurang efektif.

\section{Uji N-Gain kelas kontrol 1}

Hasil Uji N-Gain kelas kontrol 1 menunjukan nilai rata-rata yang diperoleh 0,43 dengan demikian berada dalam kategori sedang. Dan nilai pengambilan keputusan tafsiran efektivitas uji N-GAIN sebesar 43,04 berada pada kategori kurang efektif.

\section{Uji N-Gain kelas kontrol 2}

Hasil Uji N-Gain kelas kontrol 2 menunjukan nilai rata-rata yang diperoleh 0,38 dengan demikian berada dalam kategori sedang. Dan nilai pengambilan keputusan tafsiran efektivitas uji N-GAIN sebesar 38,34 berada pada kategori cukup efektif.

\section{Uji N-Gain kelas kontrol 3}

Hasil Uji N-Gain kelas kontrol 3 menunjukan nilai rata-rata yang diperoleh 0,33 dengan demikian berada dalam kategori sedang. Dan nilai pengambilan keputusan tafsiran efektivitas uji N-GAIN sebesar 32,73 berada pada kategori tidak efektif.

\section{B. Pembahasan}

Menurut (Zubaidah, 2010) Kemampuan Berpikir Tingkat Tinggi Sebagai Kemampuan Dalam Menerapkan Sebuah Pengetahuan, Keterampilan, Dan NilaiNilai Dalam Membuat Penerapan Sehingga Peserta Didik Dapat Memecahkan Suatu Permasalahan, Mengambil Tindakan, Dan Mampu Meciptakan Sesuatu Yang Bersifat Inovatif Atau Kreatif. Higher Order Thinking Skill (Hots) Memiliki Ciri Khas Level Kemampuan Ini Mencakup Kemampuan Atau Keterampilan Peserta Didik Dalam Indikator C4: Menganalisis (Analyze), C5: Mengevaluasi (Evaluate), C6: Menciptakan (Create).

Implementasi Kurikulum 2013 Menurut Permendikbud No. 22 Tahun 2016 Tentang Standar Proses Menggunakan 3 (Tiga) Model Pembelajaran Yang Diharapkan Dapat Membentuk Perilaku Saintifik, Sosial Serta Mengembangkan Rasa Keingintahuan. Ketiga Model Tersebut Adalah: Model Pembelajaran Melalui Penyingkapan/Penemuan (Discovery/Inquiry Learning), Model Pembelajaran Berbasis Masalah (Problem-Based Learning/Pbl), Dan Model Pembelajaran Berbasis Projek (Project- Based Learning/Pjbl) (Nurdyansyah \& Fahyuni, 2016).

\section{Hasil Belajar Higher Order Thinking Skill (HOTS) dengan model pembelajaran melalui penyingkapan/penemuan (Discovery/Inquiry Learning)}

Model pembelajaran penyingkapan/penemuan (Dicovery/inquiry Learning) adalah memahami konsep, arti, dan hubungan melalui proses intuitif untuk akhirnya sampai kepada suatu kesimpulan. Discovery terjadi bila individu terlibat terutama dalam penggunaan proses mentalnya untuk menemukan beberapa konsep dan prinsip. 
Discovery dilakukan melalui observasi, klasifikasi, pengukuran, prediksi, penentuan dan inferensi. Proses tersebut disebut cognitive process sedangkan discovery itu sendiri adalah the mental process of assimilating concepts and principles in the mind (Saraswati \& Rohayati, 2020).

Berdasarkan hasil penelitian yang di lakukan dengan menerapkan Model Pembelajaran Melalui Penyingkapan/Penemuan (Discovery/Inquiry Learning), hasil belajar Higher order thinking skill (HOTS) dapat meningkat dengan kategori sedang dengan dengan tafsiran cukup efektif lebih lanjut lagi dibandingkan dengan kelas yang mengontrol (kelas yang tidak menerapkan Discovery/Inquiry Learning).

Terbukti dengan melihat data beda dua rata-rata dengan hasil penelitian antara kelas eksperimen dengan kelas kontrol bahwa kelas yang menggunakan model Pembelajaran Melalui Penyingkapan/Penemuan Discovery/Inquiry Learning lebih tinggi di badingkan dengan kelas yang tidak menerapkan Discovery/Inquiry Learning.

Penelitian ini didukung dengan penelitian yang di lakukan oleh Diyas Age Larasati tahun 2019 menyatakan bahwa, Hal tersebut membuktikan bahwa terdapat pengaruh model discovery learning berbasis higher order thinking skill terhadap hasil belajar Higher order thinking skill (HOTS).

Dan juga menurut Kristin Natalia Tondang dan Sahyar tahun 2016 Hasil penelitian menunjukkan adanya positif pengaruh model discovery learning terhadap berpikir tingkat tinggi siswa keterampilan di kelas eksperimen atau diberikan oleh model penemuan.

Terbukti dari hasil post test di kelas eksperimen lebih tinggi dari kelas kontrol atau ada ada perbedaan yang signifikan dari skor post test, meskipun dalam urutan yang lebih tinggi tingkat berpikir, kedua kelas masih dalam taraf kurang, tetapi siswa yang diberikan discovery learning memiliki nilai yang lebih tinggi dibandingkan kelas kontrol.

2. Hasil Belajar Higher Order Thinking Skill (HOTS) dengan model pembelajaran berbasis masalah (Problem-based Learning/PBL)

Pembelajaran berbasis masalah merupakan pembelajaran yang menggunakan berbagai kemampuan berpikir dari peserta didik secara individu maupun kelompok serta lingkungan nyata untuk mengatasi permasalahan sehingga bermakna, relevan,dan kontekstual (Saraswati \& Rohayati, 2020).

Tujuan PBL adalah untuk meningkatkan kemampuan dalam menerapkan konsep - konsep pada permasalahan baru/nyata, pengintegrasian konsep Higher Order Thinking Skills (HOT's), keinginan dalam belajar, mengarahkan belajar diri sendiri dan keterampilan (Norman and Schmidt) (Naibaho, 2021).

Berdasarkan hasil penelitian yang di lakukan dengan menerapkan Model Pembelajaran Berbasis Masalah (Problem-based Learning/PBL), hasil belajar Higher order thinking skill (HOTS) dapat meningkat dibandingkan dengan kelas yang mengontrol dengan nilai rata-tara kelas eksperimen lemih tinggi dari pada 
kelas yang mengontrol (kelas yang tidak menerapkan Problem-based Learning/PBL).

Terbukti dengan melihat data beda dua rata-rata dengan hasil penelitian antara kelas eksperimen dengan kelas kontrol bahwa kelas yang menggunakan Model Pembelajaran Berbasis Masalah (Problem-based Learning/PBL) lebih tinggi di badingkan dengan kelas yang tidak menerapkan Problem-based Learning/PBL.

Hasil penelitian ini sejalan dengan penelitian yang dilakukan oleh Kristin Natalia Tondang dan Sahyar bahwa Hasil penelitian menunjukkan adanya pengaruh positif antara model discovery learning terhadap berpikir tingkat tinggi siswa. Terbukti dari hasil post test di kelas eksperimen lebih tinggi dari kelas kontrol atau ada ada perbedaan yang signifikan dari skor post test dibandingkan kelas kontrol.

3. Hasil Belajar Higher Order Thinking Skill (HOTS) Dengan Model Pembelajaran Berbasis Projek (Project- based Learning/PJBL).

Model Project-based Learning adalah model pembelajaran yang melibatkan keaktifan peserta didik dalam memecahkan masalah, dilakukan secara berkelompok/mandiri melalui tahapan ilmiah dengan batasan waktu tertentu yang dituangkan dalam sebuah produk untuk selanjutnya dipresentasikan kepada orang lain (Handayani, 2020).

Berdasarkan hasil penelitian yang di lakukan dengan menerapkan Model Pembelajaran Berbasis Projek (Project- based Learning/PJBL), hasil belajar Higher order thinking skill (HOTS) dapat meningkat dibandingkan dengan kelas yang mengontrol dengan nilai rata-tara kelas eksperimen lemih tinggi dari pada kelas yang mengontrol (kelas yang tidak menerapkan Model Pembelajaran Berbasis Projek (Project- based Learning/PJBL).

Terbukti dengan melihat data beda dua rata-rata dengan hasil penelitian antara kelas eksperimen dengan kelas kontrol bahwa kelas yang menggunakan Model Pembelajaran Berbasis Projek (Project- based Learning/PJBL) lebih tinggi di badingkan dengan kelas yang tidak menerapkan Project- based Learning/PJBL.

Hasil penelitian ini sejalan dengan penelitian yang di lakukan Nur Hidayah Alawi1,Tuan Mastura dan Tuan Soh2 bahwa, Hasil menunjukkan bahwa ada berpengaruh signifikan terhadap Model Pembelajaran Berbasis Projek (Projectbased Learning/PJBL) secara efektif meningkatkan keterampilan berpikir kritis siswa yang merupakan salah satu elemen kunci dalam pendidikan STEM.

Terbukti dari hasil post test di kelas eksperimen lebih tinggi dari kelas kontrol atau ada ada perbedaan yang signifikan dari skor post test dibandingkan kelas kontrol.

4. Perbedaan hasil belajar Higher Order Thinking Skill (HOTS) secara keseluruhan pada kelas eksperimen dan kelas kontrol

Berdasarkan hasil penelitian yang di lakukan, pembelajaran dengan mengunakan model pembelajaran Higher order thinking skill (HOTS), dapat 
meningkatkan hasil belajar di bandingkan dengan kelas yang tidak menerapkan model pembelajaran Higher order thinking skill (HOTS). Dilihat dari nila rata-rata kelas yang menggunakan model pembelajaran Higher order thinking skill (HOTS) lebih tinggi di bandingkan dengan kelas yang tidak menngunakan Higher order thinking skill (HOTS).

Terbukti dengan melihat uji keseluruhan hasil penelitian antara kelas eksperimen dengan kelas kontrol bahwa kelas yang menggunakan model pembelajaran Higher order thinking skill (HOTS) lebih tinggi di badingkan dengan kelas yang tidak menerapkan model pembelajaran Higher order thinking skill (HOTS).

Hasil penelitian ini sejalan dengan penelitian yang dilakukan oleh peneliti sebelumnya, hasil penelitian menunjukkan adanya pengaruh positif antara kelas eksperimen dan kontrol.

\section{Kesimpulan}

Dari penelitian yang dilakukan maka dapat disimpulkan bahwa: pertama, Berdasarkan hasil penelitian yang di lakukan dengan menerapkan Model Pembelajaran Melalui Penyingkapan/Penemuan (Discovery/Inquiry Learning), hasil belajar Higher order thinking skill (HOTS) dapat meningkat dengan kategori sedang dengan dengan tafsiran cukup efektif lebih lanjut lagi dibandingkan dengan kelas yang mengontrol (kelas yang tidak menerapkan Discovery/Inquiry Learning). Dengan demikian jika sekolah menggunakan/menerapkan model Pembelajaran Melalui Penyingkapan/Penemu (Discovery/Inquiry Learning), hasil belajar Higher order thinking skill (HOTS) dapat meningkat. kedua, Berdasarkan hasil penelitian yang di lakukan dengan menerapkan Model Pembelajaran Berbasis Masalah (Problem-based Learning/PBL), hasil belajar Higher order thinking skill (HOTS) dapat meningkat dibandingkan dengan kelas yang mengontrol dengan nilai rata-tara kelas eksperimen lemih tinggi dari pada kelas yang mengontrol (kelas yang tidak menerapkan Problem-based Learning/PBL). Dengan demikian jika sekolah menggunakan/menerapkan model Pembelajaran Berbasis Masalah (Problem-based Learning/PBL), hasil belajar Higher order thinking skill (HOTS) dapat meningkat. Ketiga, Berdasarkan hasil penelitian yang di lakukan dengan menerapkan Model Pembelajaran Berbasis Projek (Project- based Learning/PJBL), hasil belajar Higher order thinking skill (HOTS) dapat meningkat dibandingkan dengan kelas yang mengontrol dengan nilai rata-tara kelas eksperimen lemih tinggi dari pada kelas yang mengontrol (kelas yang tidak menerapkan Model Pembelajaran Berbasis Projek (Project- based Learning/PJBL). Dengan demikian jika sekolah menggunakan/menerapkan model Pembelajaran Berbasis Projek (Project- based Learning/PJBL), hasil belajar Higher order thinking skill (HOTS) dapat meningkat. 


\section{BIBLIOGRAFI}

Amir, Mohammad Faizal. (2015). Pengaruh pembelajaran kontekstual terhadap kemampuan pemecahan masalah matematika siswa sekolah dasar. Prosiding Seminar Nasional Pendidikan, 34-42.Google Scholar

Bali, MMEI, \& Hajriyah, Hilya Banati. (2020). Modernisasi Pendidikan Agama Islam di Era Revolusi Industri 4.0. Momentum: Jurnal Sosial Dan Keagamaan, 9(1), 4262. Google Scholar

Basis, Umiyati Annisaa, Manongko, Allen, \& Tiwow, Gilly M. (2020). Model Pengembangan Pembelajaran Higher Order Thingking Skill (Hots) Pada Siswa Di Sma Kristen 1 Tomohon. Literacy-Jurnal Pendidikan Ekonomi, 1(2), 20-36. Google Scholar

Fauzi, Achmad, Zainuddin, Zainuddin, \& Atok, Rosyid. (2018). Penguatan karakter rasa ingin tahu dan peduli sosial melalui discovery learning. Jurnal Teori Dan Praksis Pembelajaran IPS, 2(2), 83-93. Google Scholar

Gunawan, Heri. (2012). Pendidikan karakter. Bandung: Alfabeta, 2(1). Google Scholar

Handayani, Lilik. (2020). Peningkatan Motivasi Belajar IPA Melalui Model Pembelajaran Project Based Learning pada Masa Pandemi Covid-19 bagi Siswa SMP Negeri 4 Gunungsari. Jurnal Paedagogy, 7(3), 168-174. Google Scholar

Ilham, Dodi. (2019). Menggagas Pendidikan Nilai dalam Sistem Pendidikan Nasional. Didaktika: Jurnal Kependidikan, 8(3), 109-122. Google Scholar

Mulyati, Mulyati. (2019). Pengaruh Penggunaaan Pendekatan Cooperative Learning Tipe Numbered Head Together (Nht) Terhadap Hasil Belajar Mata Pelajaran Ips Terpadu Pada Siswa Kelas Vii 1 Smpn 1 Lembar Tahun Pelajaran 2018/2019. Universitas Muhammadiyah Mataram. Google Scholar

Naibaho, Tutiarny. (2021). Paradigma Pembelajaran Bermakna. Manajemen Pembelajaran, 39. Google Scholar

Nurdyansyah, Nurdyansyah, \& Fahyuni, Eni Fariyatul. (2016). Inovasi model pembelajaran sesuai kurikulum 2013. Nizamia Learning Center. Google Scholar

Purba, Mhd, \& Basni, Alfach Reza. (2020). Pengembangan LKPD (Lembar Kerja Peserta Didik) Berbasis HOTS (Higher Order Thinking Skills) Untuk Meningkatkan Kemampuan Pemecahan Masalah Tema Berbagai Pekerjaan Subtema Jenis-Jenis Pekerjaan di Kelas IV MIS Islamiyah Sunggal. Universitas Islam Negeri Sumatera Utara Medan. Google Scholar

Saraswati, Saraswati, \& Rohayati, Rohayati. (2020). Pembelajaran Bahasa Indonesia Berorientasi Hots Materi Teks Laporan Hasil Observasi Melalui Model Discovery Learning Siswa Kelas VII Semester Ganjil pada SMP Islam Terpadu Assalam 
Tahun Pelajaran 2019/2020. Jurnal Artikula, 3(1), 12-19. Google Scholar

Setiawan, Monji. (2018). Peran Sekolah Yang Menerapkan Sistem Full Day School Dalam Mengontrol Perilaku Menyimpang Siswa (Studi kasus: SMA PKP Jakarta). Jakarta: Fakultas Ilmu Sosial Dan Ilmu Politik UIN Syarif Hidayatullah. Google Scholar

Sugiyono, Prof Dr. (2010). Metode penelitian pendidikan. Pendekatan Kuantitatif. https://opac.perpusnas.go.id/DetailOpac.aspx?id=281396. Google Scholar

Undang-Undang 2003, No 20. (2003). Tahun 2003 tentang sistem pendidikan nasional. https://jdih.kemdikbud.go.id/arsip/UU_tahun2003_nomor020.pdf. Google Scholar

Widyastuti, Astriana. (2012). Analisis hubungan antara produktivitas pekerja dan tingkat pendidikan pekerja terhadap kesejahteraan keluarga di Jawa Tengah tahun 2009. Economics Development Analysis Journal, 1(2). Google Scholar

Zubaidah, Siti. (2010). Berpikir Kritis: kemampuan berpikir tingkat tinggi yang dapat dikembangkan melalui pembelajaran sains. Makalah Seminar Nasional Sains Dengan Tema Optimalisasi Sains Untuk Memberdayakan Manusia. Pascasarjana Unesa, 16, 1-14. Google Scholar

\section{Copyright holder:}

Harkinal Mikly, Arie Frits Kawulur, Allen Manongko, Edwin Wantah (2021)

\section{First publication right:}

Syntax Idea

This article is licensed under: 